\title{
İslam Ekonomisi Açısından Beşeri ve Sosyal Sermaye Kavramlarının Eleştirel Bir Analizi
}

\author{
Harun ŞENCAL*
}

İstanbul 29 Mayıs Üniversitesi

Öz

Kişinin kendisiyle ve çevresiyle kurduğu ilişkideki dönüşüm sonucu ortaya çlkan beşeri ve sosyal sermaye kavramlarını merkezine alan bu çalışma, İslam ekonomisinin varlık ve bilgi anlayışından yola çıkarak bu kavramları eleștirel bir analize tabi tutmayı hedeflemektedir. İslam ekonomisi açısından, kişinin başta kendisi olmak üzere, ailesi, akrabaları, komşuları ve arkadaşları ile kurması gereken ilişki biçimi ve bu ilişkinin gereklilikleri İslam ahlakı prensipleri çerçevesinde normatif bir şekilde belirlenmektedir. Günümüz kapitalist piyasa sistemi tarafından șekillenen toplumlarda ise söz konusu ilişkilerin beşeri ve sosyal sermaye olarak tanımlanması ve ekonomik bir sermayeye dönüştürülebilir doğası üzerinden anlam yüklenmesi kapitalist bakış açısının insanlar arasındaki ilişkilerin doğasına da sirayet ettiğine işaret etmektedir. Kapitalist piyasa sistemi tarafından şekillenen bu ilişkiler, İslam ekonomisinin varlık anlayışı çerçevesinden insanın yaratılış amacı olan Allah'a kulluk üzerinden tanımlanmakta ve bu ilişkilerin bir meta haline gelmeme gerekliliği vurgulanmaktadır. $\mathrm{Bu}$ bağlamda çalışma, beșeri ve sosyal sermaye kavramlarının analizinden sonra bu ilişkilerin toplumsal düzeyde içselleștirilmesinin temel enstrümanı olan okul kurumunu (i) eğitimin amacı, (ii) eğitimin veriliş şekli ve (iii) eğitim müfredatının içeriği başlıkları üzerinden eleştirel bir analize odaklanmıştır.

\section{Anahtar Kelimeler}

Beşeri Sermaye, Sosyal Sermaye, Okul, İslam Ekonomisi, Kapitalizm

* Dr. Öğr. Üyesi Harun Şencal, İktisadi ve İdari Bilimler Fakültesi, Ekonomi Bölümü, 


\title{
A Critical Analysis Of Human a And Social Capital Concepts From The Perspective Of Islamic Economics
}

\begin{abstract}
This study, which focuses on the concepts of human and social capital that emerged as a result of the transformation of the relationship that a person establishes with himself and with his environment, aims to critically analyze these concepts, based on the understanding of the ontology and epistemology of Islamic economics. From the perspective of Islamic economics, the form of relationship that a person should establish with herself, family, relatives, neighbors and friends and the requirements of this relationship are normatively determined according to Islamic moral principles. In societies that are shaped by contemporary capitalist market system, defining these relations as human and social capital and attributing meaning to their nature that can be transformed into an economic capital signifies that the capitalist perspective shapes the nature of the relationship among the people. It is emphasized that these relations, which have been shaped by the capitalist market system, should be defined in terms of servitude to Allah, the purpose of human creation, and the necessity of these relations not to become a commodity from the ontological framework of Islamic economics. After the analysis of the concepts of human and social capital, the study focuses on a critical analysis of the school institution, which is the main instrument of internalizing these relations at the societal level, through the titles of (i) the purpose of education, (ii) the way of delivery of education, and (iii) the content of the education curriculum.
\end{abstract}

\section{Keywords}

Human Capital, Social Capital, School, Islamic Economics, Capitalism

\section{Extended Abstract}

Following the emergence of capitalist market system in the West and its expansion towards other societies, we witness the transformation of institutions and relationships throughout the world in line with the principles of capitalist market system in the last two centuries. This study focuses on the concepts of human and social capital that emerged because of the transformation of the relationship that a person establishes with himself and with his environment and aims to critically analyze these concepts based on the understanding of the ontology and epistemology of Islamic economics. The initial recognition of humans as capital can be traced back to Adam Smith. Although he did not conceptualize "human capital" as a term, he treated the labor as capital in the production process. In contemporary period, however, human capital as a concept plays a central role in education and production process. It refers to the skills and knowledge of labor that can be used in the production process. Hence, knowledge of a language and writing and speaking skills in that language is part of human capital that could be accumulated (i.e. learned) by an individual. Accumulation of such capital may increase the productive capacity of a labor provided that the acquired skills and knowledge are beneficial in the production process. However, this process is not limited solely to an accumulation process but also transform how an individual establishes a relationship with himself. The individuals who consider and value themselves as an input in the capitalist production system have a view of themselves as a commodity which should increase in value through accumulation of human capital. As an outcome of this understanding, an individual is expected to accumulate capital continuously, either in the form of human capital or other forms of capital. Another important form of capital is the social capital, which refers to the connections one has that could be converted into economic capital in the long-term. In other words, social capital refers 
to the network relations including the family, friends, neighbors, and work. Both human capital and social capital can be converted into economic capital. Therefore, in modern capitalist system, economic capital is not the only mean to be a capitalist, but individuals can be a successful capitalist through accumulation of human and social capital by different means and convert these capitals into economic capital in the long term. In societies that are shaped by contemporary capitalist market system, defining these relations as human and social capital and attributing meaning to their nature that can be transformed into an economic capital signifies that a capitalist perspective shapes the nature of the relationship among the people. From the perspective of Islamic economics, however, the form of relationship that a person should establish with himself, family, relatives, neighbors and friends and the requirements of this relationship are normatively determined according to Islamic moral principles. It is emphasized that these relations, which have been shaped by the capitalist market system, should be defined in terms of servitude to Allah, the purpose of human creation, and should not be commodified, from the perspective of Islamic economics.

After the analysis of the concepts of human and social capital, a critical analysis of the school institution, which is the main instrument of internalizing these relations at the societal level, is conducted through the titles of (i) the purpose of education, (ii) the way of delivery of education, and (iii) the content of the education curriculum. The main purpose of the school institution as the educational institution of the capitalist market system is to train and discipline children as a worker or human capital to become an input in the production process and a good citizen of the nation-state construct. The method of delivery of education, therefore, is mostly limited to transfer of required skills and knowledge based on age clusters in a disciplinary environment. The curriculum is constructed according to the necessities and requirements of capitalist system and nation-state, which exclude unproductive elements from the curriculum unless they facilitate the production process or increase the efficiency. Therefore, a certain level of morality is a must in such an education to encourage worker-to-be children to obey the laws in public places as well as private.

From the perspective of Islamic economics, it is necessary to make a distinction between technical education and the education required to reach the truth. The acquisition of certain knowledge and skills is important for one's livelihood, but it is only a means to an end. Although it is necessary to pursue halal sustenance by acquiring a craft or profession, the basis and purpose of education should be to acquire knowledge of the truth. What is meant by the knowledge of truth here is to know God and to learn to worship Him alone, which is the purpose of creation, as stated in the Quran. The concept of worship used here refers to a meaning that includes not only rituals, but also the consciousness of being a servant at every moment of one's life. Therefore, the education cannot be devoid of morality, in the case of Islamic economics, morality of Islam. Also, such morality is not limited to only everyday life practices but encompass each and every aspect of life, including the pursue of sustenance. The method of education, hence, cannot be limited to transfer of skills and knowledge but also includes internalization of the morality of Islam and its articulation in everyday practice. As for the curriculum, deconstruction of the relations and institutions that makes the modern world is required to be an important part of the curriculum to realize the reality people are living in. However, discussions on the nature of the institutions and relations in line with the Islamic sources and historical experience should also be included in the curriculum and how they can be built in practice. 


\section{Giriş}

Kapitalist piyasa sistemi toplumu şekillendirerek toplumsal kurumlar ve toplumu oluşturan kişiler arasındaki ilişkiler üzerinde büyük dönüşümlere sebep olmuştur (Polanyi, 2001: 71-80). Bu çalışmanın amacı, modern dönemde toplumu oluşturan bireylerin kendileri ve sosyal çevreleriyle kurdukları ilişkileri beşeri ve sosyal sermaye kavramları üzerinden inceleyerek kapitalist piyasa prensiplerinin etkisiyle ortaya çıkan ve toplumun geniş bir kitlesinde görülen bu iki ilişki türünün İslam ekonomisi açısından eleştirel bir analizini yapmaktır. Ayrıca, son bölümde, bu iki ilişki türünün -bireylerin karakteristik özellikleri sebebiyle- sınırlı sayıda kişiyle kayıtlı kalmayıp toplumun genelinde gözlemlenebilir bir yaygınlığa kavuşmasının aracı olarak da okul kurumu incelenecektir.

Kavramsal köklerini Adam Smith'in Ulusların Zenginliği kitabına kadar götürebileceğimiz beșeri sermaye (human capital) kavramı (Laroche vd., 1999: 87), üretim sürecinin bir girdisi olan insanın kapitalist piyasa sistemi içerisinde metalaşması neticesinde ortaya çıkmıştır (Polanyi, 2001: 75-76). Sanayi kapitalizmi sırasında daha ziyade disiplinli bir şekilde fazla beceri gerektirmeyen komutları fabrika üretim bandında yerine getirmekle görevli işçiler için üretim sürecine yeniden dahil olmak için gerekli şey -dinlenmek, uyku ve yemek gibi araçlar sayesinde- emeğin yeniden üretilmesiydi (Vivarelli, 2014: 129). Ancak kapitalizmin sonraki evrelerine geçildikçe ortaya çıkan yeni ürün ve hizmetler için bu beceriler yeterli olmamaktadır (Powell ve Snellman, 2004: 209; Vivarelli, 2014: 129). Günümüz kapitalist üretim sisteminde ihtiyaç duyulan "iş̧̧ilerin" dil bilme, sunum yapabilme, inovatif olma, insiyatif alma gibi birçok beceriye sahip olması beklenmekte ve gerek duyulmaktadır (Ducatel, 1998: 18). İş dünyasının bu talebini karşılamak için okullarda verilen müfredatlar uygun beceri ve donanımların -kurumsal sınırlılıklar dahilinde- öğrencilere aktarılması için çalışılırken (Wolf ve Wright, 2014: 180), öğrencilerin sürekli yeni beceriler edinmeleri ve kendilerini geliştirmeleri gerekliliği bir farkındalık olarak kazandırılmaya çalışılmaktadır (Fischer, 2000; Knapper ve Cropley, 2000). Bunun neticesinde en önemli sermayesi emeği olan yeni işçi sınıfı, kapitalist üretim sürecinde yer alabilmek ve kariyerinde ilerleyebilmek için bu sermayeyi sürekli arttırma, diğer bir deyişle sürekli yeni bilgi, tecrübe ve beceriler edinme gayreti içerisine girmek zorundadır.

Kişinin kendisiyle kurduğu ilişki beşeri sermaye kavramı üzerinden açıklanabilirken, çevresindeki kişilerle kurduğu ilişkiyi açıklayabilmek için de 
Bourdieu'nun sosyal sermaye kavramı kullanılabilir (Bourdieu, 1986: 247250). Ekonomi teorisinin dar bakış açısı sebebiyle bir sermaye olarak değerlendirilmemiş olan sosyal sermaye (Bourdieu, 1986: 241-242), ekonomik sermayenin sosyal ilişkileri geliştirmek için kullanılarak uzun vadeli bir yatırım ve gelecekte ekonomik sermaye kazandıracak bir yapıya dönüștürülebilir olması ve insanların -kapitalist sistem içerisinde- başarıya ulaşmasında ekonomik sermaye gibi bir rol oynayabilmesi sebebiyle bir sermaye olarak değerlendirilebilir (Bourdieu, 1986: 251). Bazı insanlar bu sermayeye -aile bağları sebebiyle- doğuştan sahip olabilirken, diğer insanların bu sermayeyi zaman içerisinde elde etmesi, biriktirmesi ve koruması gerekmektedir (Bourdieu, 1986: 247).

İslam ekonomisi açısından düşünüldüğünde kişinin kendisi, komşuları, akrabaları ve arkadaşları ile kurması gereken ilişki ve bu ilişkinin gereklilikleri normatif bir şekilde İslam ahlak prensipleri ile şekillenirken, bu ilişkilerin beşeri ve sosyal sermaye olarak tanımlanması ve ekonomik bir sermayeye dönüştürülebilir doğası üzerinden anlam yüklenmesi kapitalist bir bakış açısının insanlar arasındaki ilişkilerin doğasını da belirlediğine işaret etmektedir. İnsanların kendileri ve çevresindekilerle kurdukları ilişkileri bu şekilde sermaye eksenli görmelerinin toplumsal bir fenomen halini alması modern eğitim sisteminin kapitalist prensiplerin öğrencilere aktarılması için önemli bir araç olmasından kaynaklanır (Boyles, 2000). Bu sebeple son bölümde okul kurumunun beşeri ve sosyal sermaye elde etme açısından araçsal rolü ele alınacaktır.

Bu çalışma girişten sonra üç temel bölümden oluşmaktadır. İkinci bölümde beşeri sermaye kavramı incelenip İslam ekonomisi açısından eleştirel bir analize tabi tutulurken, üçüncü bölüm sosyal sermayeyi aynı açıdan ele almaktadır. Dördüncü bölümde ise, insanların beşeri ve sosyal sermaye kavramlarını içselleştirmesinin aracı kurumu olarak okul incelenmiştir. Son bölümde sonuç ve değerlendirmeler sunulmuştur.

\section{Beșerî Sermaye}

Kapitalist piyasa sisteminin kendi ilkeleri ile şekillendirdiği toplumsal bir yapıda, toplum da dönüșerek kapitalist sisteme uygun bir hale gelmektedir (Polanyi, 2001: 74). Sisteme uygun hale gel(e)meyen her ilişki ve kurum, bu toplumsal yapının tanımladığı "normal" olma şartlarını taşımadığından "anormal" bir ilişki veya kurum olarak görülmektedir. Bu "anormal" oluşumların çeşit ve sayıları kapitalist piyasa sisteminin toplumda ne kadar egemen olduğuna ve yeni nesillerin aldıkları eğitimin ne ölçüde bu sisteme uygun "ilkeler" doğrultusunda gerçekleştiğine bağlı olarak değiş̧ebilmektedir. Kapitalist piyasa sisteminin hakim olduğu bir toplumda kişinin kendisiyle ilişkisini bu bölümde incelerken, sonraki bölümde kişinin yakın çevresiyle olan ilişkisi incelenecektir. 
Sanayi devriminin şafağında yaşanan mülkiyet anlayışındaki dönüşüm neticesinde ekip biçebileceği toprağı elinden alınan insanlar, Sanayi Devrimi ve özellikle Fordist üretim bandı sayesinde kendilerini "vasıfsız işçi" olarak fabrikalarda çalışırken buldular. Bu işçilerden beklenen, çok basit ve tekrar eden işlerin disiplinli ve verimli bir şekilde yapılmasıydı. İşçilerin çalışmaya hazır hale gelmesi için gereken eğitim çok kısa olduğu için kolaylıkla değiştirilebilir görülen bu "üretim girdisi”nin yeni şeyler öğrenerek kendisini geliştirmesi gerekmezken, sadece bir sonraki iş gününe "emek gücü"nü tekrar yaratmış olarak gelmesi yeterli görülmüştür. Bu sebeple, sanayi kapitalizmi olarak ifade edilen bu dönemde işçiler için eğitimden ziyade disiplin daha önemliydi diyebiliriz. 1970'ler sonrasında ortaya çıkan post-fordizm döneminde ise üretim daha esnek bir yapıya evirilmeye başlamıştır (Macdonald, 1991: 177). Bunun neticesinde, 1970 ve sonraki dönemde büyük ölçekli seri üretim yapısı için ihtiyaç duyulan disiplinli ve vasıfsız işçi ihtiyacı yerini gerekli becerilere sahip, inovatif düşünebilen eğitimli işçi ihtiyacına bırakmıştır (Ducatel, 1998: 18; Vivarelli, 2014: 129). Günümüzde beyaz yakalı olarak isimlendirilen bu işçi tipinin tek dert edinmesi gereken şey bir gün sonrası için "emek gücü”nü yeniden yaratmak değil, aynı zamanda ișini korumasına ve kariyer basamaklarını çıkmasına yardımcı olacak gerekli bilgi ve becerileri elde etmek için çabalayarak "beşeri sermaye"sini arttırmaktır (Rosen, 1983: 44; Schultz, 1961: 3).

Modern toplumu şekillendiren kapitalist piyasa sistemi eskiden beri süregelen ilişki ve kurumların içini uzun bir süreçte kendi ilkeleri doğrultusunda dönüştürmeyi başarmıştır. Yaşanan büyük dönüşümlerin birçoğu içine doğduğumuz bu modern dünyanın gündelik koşturmacaları içerisinde hissedilememektedir. Beşerî sermaye kavramı da kişinin kendisiyle olan ilişkisine dair önemli bir dönüşümü temsil etmektedir. Kendisini kapitalist piyasa sisteminin içerisindeki üretim girdilerinden birisi olarak gören beyaz yakalı işçi, üretimdeki rolünü arttırabilmek, daha fazla sorumluluk ve dolayısıyla maaş alabilmek için kendisine yatırım yapmalıdır (Schultz, 1961: 3). Diğer bir ifadeyle, beșerî sermayesini arttırmak için sürekli "kendini geliştirmesi” gerekmektedir.

İnsanların bilgi ve beceri edinmek için çaba sarf ettiğini modern öncesi toplumlarda da görebiliriz. Örneğin, İslam dininin esaslarını daha iyi öğrenmek amacıyla bazı sahabelerin suffe mektebine katılmasını (Yilmaz, 2012: 210211) ve Zeyd bin Sâbit'in (ö. 45/665[?]) İbrânice öğrenmesini zikredebiliriz (Güngör, 1993). Önemli Hanefî âlimlerinden olan Cessâs'ın (ö. 370/980), geçimini sağlamak için kireççilik mesleğini öğrenmesi ve sonrasında bu yaptığı uğraşla anılarak Cessâs (kireççi) lakabını alması klasik dönemden bir örnek olarak verilebilir (Güngör, 1993). Osmanlı dönemine baktığımızda, özellikle Kânuni döneminde imparatorluğun sınırlarının da genişlemesiyle birlikte, medreselerde eğitim gören kişiler için bürokratik denebilecek bir yapıya dahil olmak ve adım adım yükselme imkânı da ortaya çıkmıştır (Atçıl, 2018: 
83-116). Peki bu örneklerdeki kişilerin çabaları "beșerî sermaye"lerini arttırarak "kariyer" peşinde koşmak olarak tanımlanabilir mi?

İlk bakışta görülebileceği üzere burada hem nitelik hem de nicelik bakımından farklılıklar vardır. En bașta Hz. Peygamber'in (s.a.s) emriyle dil öğrenen veya Kuran ayetlerini ezberleyerek hayatlarına tatbik etmeye çalışan sahabelerin bu çabalarını ibadet ve Allah'a iyi bir kul olma kaygısıyla gösterdikleri rahatça iddia edilebilir. Cessâs gibi kapitalist üretim modelinin baskın olmasından önce çeşitli zanaâtler öğrenerek para kazanan kişilerin de amacının geçimlerini sağlamak olduğu söylenebilir. Cessâs bu bağlamda önemli bir örnektir, çünkü mesleği ile özdeşleşmiş lâkabına rağmen, mesleğindeki maharetleriyle değil, önemli bir Hanefî âlimi olarak ortaya koyduğu eserleri sebebiyle tanınmaktadır. Bunun sebebi, mesleği hakkındaki bilgi ve becerileri geçimini sağlamak için icrâ ettiği bir "uğraş" ile ilgiliyken, asıl meşguliyetinin ilim olması ve bunu kariyer merdivenlerini çıkmak için yapmamasıdır; zaten, ortada böyle bir merdiven tasavvuru da yoktur. Diğer yandan Osmanlı bürokrasisi içerisinde "yükselme" diyebileceğimiz ilerleme, günümüzdeki kariyer olanaklarına en yakın modern öncesi örnek olabilir. Yakındır, fakat yine de aynısı değildir. Çünkü kapitalist piyasa sistemi içerisindeki anlamıyla "kariyer" algısının modern öncesi bir toplumsal yapı ve ilişkiler ağında olma ihtimali yoktur, bunu iddia etmek anakronizm olur.

Tecrübe ve becerileri arttı̆̆ için kişilere daha fazla sorumluluk yüklenmesi, herkes tarafından kariyer basamaklarında yükselmek olarak algılanmayabilir. Bu durum, kişinin kendisiyle nasıl bir ilişki içerisinde olduğu, kendisini nasıl gördüğü ile ilgilidir. Kişi kendisini bir meta olarak görüyor ve üretim sürecinin bir girdisi olarak tanımlıyorsa (Schultz, 1961: 3), bu durum "kariyer basamaklarını çıkmak" olarak tanımlanabilir. Ancak kişinin kendisini bu şekilde görmeye başlaması çok yeni bir gerçekliktir.

Osmanlı'daki bürokratik hiyerarşi içerisinde yükselen kişilerin kendilerini nasıl gördükleri ve kendilerine nasıl hedefler koydukları bilinemiyor olsa da toplumsal yapıları şekillendiren prensiplerin farklılığından dolayı "kariyer" kaygısı olduğunu iddia etmek mümkün görünmemektedir. Daha da önemli bir fark niteliksel olmaktan ziyade niceliksel olarak karşımızda durmaktadır. İçinde yaşadığımız kapitalist sistemde (çocuklar da dahil) herkes "beşerî sermaye" olarak görülürken, Osmanlı'daki bürokratik yapının kapısı sadece sınırlı sayıda kişiye açıktı (Atçıl, 2018: 108). Nüfusun zaten azınlıkta kalan bir kısmı medrese tahsili ile böyle bir yola girerken, bunların da yine belli bir oranı bürokratik yapı içerisine giriyordu. Diğer bir deyişle, Osmanlı klasik döneminde yaşayan insanların birçoğunun gündemini meşgul eden bir "kariyer" ilerlemesinden bahsetmek mümkün değildi.

Modern kapitalist piyasa sisteminin en önemli özelliği kapsayıcı bir yapıya sahip olmasıdır. Yani toplumun sadece bir kesimini etkileyen ve diğerlerinin habersiz olduğu veya umursamadığı bir ilişki ve kurumsal ağdan bahsetmiyoruz. 
Aksine, eğitim-öğretim ve geçim sağlama gibi temel alanlar başta olmak üzere, tüm toplumu kuşatan ve kendi ilkelerine göre şekillendiren bir sosyal formasyondan bahsediyoruz. Bunun en bariz örneklerinden biri, çocukların kariyer planlarının ebeveynleri tarafından daha ilkokul çağında, hatta çocuk doğduğu andan itibaren -okul planları ve "nitelikli okul" rezervasyonları yapılarak- başlamasıdır (Khasawneh, 2010; Magnuson ve Starr, 2000). Bu yüzden, anaokulundan üniversiteye kadar bütün eğitim ve öğretim sistemi kapitalist sistem içerisinde işgücüne dönüştürülecek beşerî sermayeler oluşturmak üzerine kuruludur.

Özetle, burada vurgulanmak istenen şudur: Kapitalist piyasa sisteminin ilkeleri tarafından şekillendirilmiş eğitimler neticesinde kişiler kendilerini bir "meta" ve üretim sürecinin girdisi olarak görmeye başlamışlardır. Post-fordizm dönemiyle beraber bu "meta", sürekli arttırılması ve biriktirilmesi gereken bir "beșerî sermaye"ye dönüşmüş, bu dönüşümün bir sonucu olarak da kişilerin bilgi ve becerilerini arttırmaları "kariyer" basamaklarında yükselmek için kullanılan bir araç haline gelmiştir. Her ne kadar diğer insanlar, örneğin işvereniniz veya bir şirketin insan kaynaklarl, sizi beşerî sermaye olarak görüyor ve bu bağlamda sizinle bir iş ilişkisi kuruyor olsa da beşeri sermaye noktasında asıl olan kişinin kendisiyle olan ilişkisidir. Bunun sebebi, insanların büyük çoğunluğunun kapitalist piyasa sistemi içerisinde çalışarak geçimlerini sağlamak zorunda kalmaları ve bu sebeple şirketler tarafından üretim sürecinin bir girdisi ve beșerî sermaye olarak görülmeleridir. Bu durum, içinde yaşanılan modern toplumsal yapının bir gerçeğidir. Buna rağmen, bu şirketler ve işverenler, kişinin kendisini nasıl gördügünü ve kendisiyle nasıl bir ilişki içerisinde olduğunu belirleyemez, sadece etkilemeye çalışır. Eğer kişi kendisini bir Müslüman olarak tanımlıyor ve çalışmayı sadece helal rızık peşinde koşmak veya diğer insanlara istifadeli olmak için bir araç olarak değerlendiriyorsa, diğer insanlar onu beșerî sermaye olarak görüyor olsa, hatta bu kapitalist üretim sürecinin içerisinde bir girdi olarak emeğini satmak zorunda kalsa dahi bu kişinin kendisini bir beșerî sermaye olarak gördüğünü iddia edemeyiz.

İslam ekonomisi açısından bakıldığında, insan, en başta Allah'a kulluk etmek için yaratılmıştır ve asli vazifesi budur (Zâriyât: 51/56). Bu sebeple, insanın bir (beșerî) sermaye olarak görülmesi, ona bir "kaynak" muamelesi yapılması mümkün değildir. İster beyaz veya mavi yakalı olsun, ister ticaret veya başka bir iş dalı ile meşgul olsun, geçimini sağlamak ve parçası olduğu sosyal yapıya istifadeli olmak için çaba göstermelidir. Fakat bunlar kendisiyle kurduğu ilişkide ancak ikincil anlama sahiptir, bu yüzden bu çabaların tamamı Allah'a kulluk üzerinden tanımlanır.

\section{Sosyal Sermaye}

Nesneler ve insanlarla olan ilişkilerimizin anlamını belirleyen birçok etken vardır ve bunların başında içinde bulunduğumuz ve parçası olduğumuz 
kurumların şekillenmesinde etkili olan prensipler gelir. Bu prensiplerin farklılığı, kişilerin aynı şeye bakarken dahi farklı anlamlar yüklemesine yol açmaktadır. Fabrikada çalışan bir işçi, müdür için bir üretim girdisinden ibaretken, aynı işçinin ailesinin gözünde çok daha farklı ve önemli, hatta vazgeçilmesi zor bir yeri olabilir. Fabrika müdürü ve işçi arasındaki ilişki kapitalist, prensiplerin egemen olduğu bir alanda geliştiği için, bu ilişkiyi tanımlayan iki tarafın rol ve görevlerini ve daha önemlisi değerini belirleyen şey de bu prensiplerdir. Aile alanına geldiğimizde ise farklı prensiplerin öncelendiğini görebiliriz. Özellikle anne-baba ve çocuğu arasındaki ilişki kapitalist prensiplerden ziyade geleneksel aile değerleri tarafından șekillenmekte ve daha ziyade toplumda egemen olan kültürün belirleyici olduğu bir ilişki șekline bürünmektedir. Peki, kapitalist prensipler aynı zamanda aileyi de şekillendirmeye bașladığında ne olur?

Sosyal sermaye kavramı, başta arkadaşlık olmak üzere (Slomczynski ve Tomescu-Dubrow, 2005) insanlar arasındaki ilişkileri bir sermaye olarak tanımlamaktadır (Bourdieu, 1986: 247-250). Bu sosyal sermaye, uygun şartlar altında ekonomik bir sermayeye dönüştürülerek kişi için bir maddi kazanç kaynağı da olabilir (Bourdieu, 1986: 251). Bu açıdan değerlendirildiğinde, sermaye biriktirmek artık para ile sınırlı olmadığından, kapitalist olmak için şirket sahibi olmak gerekmemektedir; sosyal ilişkiler de kapitalist prensiplerle idare edilebilir.

"İdeal" Batılı toplumların kapitalist piyasa sistemi ile șekillenmiş toplumsal ilişki yapısının, yine Batılı kaynaklar esas alınarak yazılmış olan eğitim sistemi üzerinden "olması gereken" gerçeklik olarak sunulması sebebiyle Batının normatif değerleri Batı haricindeki toplumlara da aktarılmaya çalışılmıştır (Rotimi, 2005; Seth, 2007). Özellikle Halkla İlişkiler gibi disiplinler başta olmak üzere bireylerin aldığı eğitim sırasında insanlar ile kurulacak ilişkilerin birer sermaye olarak görülmesi ve bu sebeple biriktirilmesi gerektiği mesajı verilmektedir (Ihlen, 2005). Çünkü artık "ne bildiğin"den ziyade "kimi tanıdığın" önem kazanmaya başlamıştır (Floress vd., 2011).

İslam ekonomisinin meselelerinden bir tanesi insanlar arasındaki ilişkinin İslam varlık ve bilgi anlayışına dayalı olarak nasıl kurulması gerektiğidir (AlSadr, 1981; Asutay, 2007; Choudhury, 2018). Uzun bir zaman ve geniş bir mekâna yayılmış olan Müslüman toplulukları meydana getiren kişilerin birbirleriyle olan ilişkilerini tek bir çeşide indirgemek mümkün değildir. Ancak bu ilişkilerin özünü oluşturması gereken temel ahlaki prensiplerden yola çıkarak ortak bir zemin bulunması mümkün olduğu gibi (Al-Bouti, 2005; Auda, 2010; Shāțibī, 1999), bu zeminden kayma olduğu takdirde eleștirel bir analiz yapılması da mümkündür. Bu yüzden sosyal sermaye kavramı daha ontolojik bir düzlemde incelenerek ortak zeminden kayma olup olmadığı araştırılmalıdır. 
Her ne kadar Batı akademisinde de sosyal sermaye kavramına dair eleştiriler yer alsa ve özellikle organize suç çeteleri, nepotizm gibi dezavantajlara vurgu yapılsa da (Ignatowski vd., 2019; Pillai vd., 2017; Villalonga-Olives ve Kawachi, 2017) İslam ekonomisi açısından bakıldığında insanın öncelikli olarak sermaye olarak görülmesi ontolojik düzeyde bir problem yaratmaktadır. Kendisini Müslüman olarak tanımlayan bir kişi diğer insanlarla olan ilişkisini de İslam üzerinden tanımlıyor olması beklenir. Diğer yandan, ulus-devlet temelli bir bakış açısı kişileri ilk olarak vatandaşlık üzerinden tanımlarken, kapitalist temelli bir ilişki de sermaye üzerinden tanımlamaktadır (bu sermaye ekonomik, sosyal veya kültürel olabilir). Yani ulus-devlet temelli bir ilişkide önemli olan karşınızdakinin Müslüman, Hıristiyan, zengin veya fakir olması değildir: Türk veya Alman vatandaşı olmasıdır. Diğer kimlikler, yani Müslüman olmak veya zengin olmak ikincil önem taşımaktadır. Aynı şekilde ilişkiler kapitalist bir temel üzerine kuruluyorsa, önemli olan muhatabın sermaye (ekonomik, kültürel veya sosyal sermaye olabilir) arttırmak için faydalı olup olmamasıdır. Muhatabının uyruğu veya dini önemli değildir. "Paranın dini olmaz" sözü bu kapitalist bağlamda anlamlı olmaktadır.

Peki, ticaret ile uğraşan bir kişinin müşterileriyle kurmaya çalıștığı ilişki nasıl bir ilişkidir? Bu soruya cevap verirken karşımıza sosyal sermaye bağlamında iki soru çıkmaktadır. Bunlardan ilki, kurulan ticari ilişkinin temelini ne oluşturuyor sorusudur. Bu soruya cevap verebilmek için bu ilişkilerin amaç mı yoksa araç mı olduğu; eğer araçsa, hangi amaca ulaşmak için araçsallaştırıldığı sorularına cevap vermemiz önemlidir. Müslüman bir tüccar genel itibariyle para kazanmak için ticaretle uğraşır. Bu noktada kapitalist bir tüccar ile Müslüman bir tüccar arasında dışarıdan bakıldığında bir fark görülmeyebilir. Fakat ikisinin amaçlarına baktığımızda kapitalist bir tüccarın daha fazla kâr yapıp bunu sermaye olarak biriktirmek ve daha sonra ticaretini daha da büyüterek daha fazla kâr ve daha fazla sermaye elde etmek şeklinde ilerleyen fâsit bir döngünün içinde olduğunu görürüz (Jorgenson ve Siebert, 1968: 1123). Bu tüccarın ilişkilerini de yine bu zeminde kurması beklenir; "ilişki ağı"na dahil ettiği kişilerin kendi hedefine, yani sermaye birikimine katkı sağlaması esastır.

Müslüman bir tüccarın ise ilk olarak Allah'ın bir kulu ve onun yeryüzündeki halifesi olduğu ve ticareti, Allah'ın emrettiği helal rızkı aramak için bir ibadet olarak, yani kulluk görevi için bir araç olarak görmesi beklenir (Orman, 2015). Bu yüzden kuracağı ticari ilişkiler maddi bir kazanç sağlasa dahi, tüccarın kulluk çerçevesindeki ilişkileri olarak ele alınabilir. Örneğin, Müslüman olmayan bir kişi ile ticaret yapıyorsa, bu ilişki aynı zamanda bir (hal ile veya sözlü olarak) tebliğ olmaktadır. Peki bu bir ideal ve aynı zamanda hayali Müslüman tüccar tiplemesi midir? Tabii ki hayır. Eğer bu tüccar sadece ideal olarak çizilmiş bir Müslüman tüccar resmi olsaydı, Hindistan ve Asya gibi İslam ile Müslüman tüccarlar vasıtasıyla tanışmış, ardından İslam’ı kabul etmiş 
toprakları nasıl açıklayabiliriz (Murphey ve Stapleton, 2019: 39; Rawlinson, 2001)?

Peki içinde yaşadığımız toplumlardaki Müslüman tüccarların davranışları bu resme ne kadar uygundur? Bu kıyas ideal durumu yargılamak için çok da uygun bir soru değildir. Çünkü içinde yaşadığımız dünyada ticaret ve eğitimle uğraşanlar (İslami ilimler de dahil) çoğunlukla kapitalist piyasa sisteminin mantığını öğreten bir eğitim sisteminden geçiyor. Bu sebeple kurulan ilişkiler de Müslüman bir tüccar olarak kurulmaktan ziyade, "dinî vecibelerini yerine getirmeye çalışan kapitalist bir tüccar" olarak kurulmaktadır. Her ne kadar Müslüman toplumlarda da İslam'ın yasakladığı akitler ile iştigal etmekten çekinmeyen tüccarlar olabilse de günümüz Müslüman toplumlarında şâhit olduğumuz durum, bu tür davranışların ve ilişki şekillerinin yüceltilmesi, Müslüman olma kaygısından dolayı -herhangi bir tür- "sermaye birikimini" reddeden kişilerin ise rasyonel olmamak gibi ithamlarla karşı karşıya kalmasıdır.

İkinci soru ise insanlara sosyal sermaye olarak yaklaşmanın sadece ticari alan ile sınırlı kalıp kalmayacağıdır. Ekonomik sermaye ve sosyal sermaye birbirlerine dönüştürülebilen sermaye türleridir (Bourdieu, 1986: 250-252). Ekonomik sermaye biriktirmiş olan bir kişi, bunu sosyal sermayesini arttırmakta, yani yeni kişilerle bağlantı kurmakta kullanabilir. Daha sonra bu sosyal sermaye daha iyi bir iș ve daha fazla maaşa dönüştürülebilir. Örneğin, ekonomik sermaye kişinin ücretli eğitim ve sertifika programlarına katılmasına imkan tanıyarak beşeri sermayesini, konferanslar ve yurtdışı yolculukları sayesinde de sosyal sermayesini arttırmasını sağlayabilir. Sermaye birikimi temelli kurulan bu sosyal ilişkiler ister istemez diğer ilişkilere de sirayet etmekte ve kişinin etrafındaki herkese sermaye birikimi gözüyle bakmasına yol açabilmektedir. Arkadaşlıklar veya hoca-öğrenci ilişkisi kolayca bunlara örnek olarak verilebilir.

Sosyal sermaye bir defa oluştuktan sonra varlığını hep devam ettiren bir şey değildir, onu sürdürebilmek için çaba sarf edilmeli ve yatırım devam etmelidir (Bourdieu, 1986: 148). Peki, işte çalışmaktan arta kalan vaktinizi hangi arkadaşlarınızla geçirmek istersiniz? Kariyerinizde ilerlemenize yardımcı olacak kişilerle mi, yoksa sevdiğiniz ve değer verdiğiniz, sizin iyi bir Müslüman olmanız için uğraşan bir arkadaşınızla mı? Bu noktada yapılan seçim kurulan ilişkilere bir Müslüman olarak mı yoksa (sosyal) sermaye birikimi peşinde olan biri olarak mı bakıldığını gösterir. Buradaki en önemli nokta seçim anlarında verilen kararın aslında kişiyi tanımlıyor olmasıdır.

Hoca ve öğrenci arasındaki ilişkide de benzer durumları görmek mümkündür. Öğrenci, sırf ileride iş imkanı sağlar ümidiyle iyi bağlantıları olan hocalarla yakınlık kurmaya çalışırken, bağlantıları olmayan hocaları, ahlaki ve ilmî açıdan daha faydalı olacağı halde önemsemiyorsa benzer bir seçim söz konusu demektir. Benzer bir ilişki ve yaklaşım tarzı hocadan öğrenciye doğru da olabilir. Görevi itibariyle en azından ilgili öğrencilerin tamamıyla ilgilenmesi 
gerekirken, sadece "aile bağları kuvvetli” veya kendi çalışmalarında kullanma ümidiyle "başarılı" bazı öğrencilerle ilgileniyorsa, benzer bir sosyal sermaye birikimi burada da geçerlidir.

Eğer ilk soruya geri dönecek olursak, ticaretle uğraşan kişilerin müşterileri ile olan ilişkilerini sosyal sermaye temelli kurması mecburi olmadığı gibi, sosyal sermaye temelli ilişkilerin sadece ticaretle uğraşan kişilere mahsus olmadığı görülmektedir. Neticede, kapitalist piyasa sistemi içerisinde var olma gayreti gösteren herkes (sosyal) sermaye biriktirme odaklı ilişkiler kurabilmektedir.

Görüldügü üzere, insanların ilişkilerinin temelini oluşturan ve karşısındaki kişiyle olan ilişkisine belli anlamlar yüklemesine sebep olan prensipler vardır. Kapitalist prensipler üzerine kurulmuş olan ilişkiler birer (sosyal) sermaye olarak algılanırken, bu sadece kapitalist bir toplum için olması gereken (normatif) ilişkiyi ifade etmektedir. Kapitalist dünya görüşünün hegemonyası arttıkça ve toplumları şekillendirmeye devam ettikçe bu durum artık toplumların gerçekliğini de temsil etmektedir.

Sosyal sermaye kavramının artan öneminden dolayı, son yıllarda yeni girişimler de ortaya çıkmıştır. Bir emlak uygulaması olan "Zingat" bunun iyi bir örneğidir. Üyelerinden veri toplamak suretiyle farklı bölgelere dair "bölge raporları" sunan bu girișim, aynı zamanda potansiyel komşuların, yani belli bir muhitte oturan kişilerin sosyoekonomik bilgilerini de toplamaktadır. Böylece standart emlak sitelerine nispeten aranan eve dair daha fazla, hatta gereğinden fazla bilgiye ulaşılmaktadır. Reklamlarında da dedikleri gibi: "Aradığınız ev yaş dağılım bilgisiyle, muhitiyle-çevresiyle, konusuyla-komşusuyla" internet sitelerinde bulunmaktadır (Zingat, 2017). Peki, atasözünde "ev alma komşu al” olarak belirtildiği gibi bu önemli ve değer arttıran bir bilgi değil midir? Buradaki asıl dönüşüm muhtemelen atalarımızın "almak" istediği komşu ile bu uygulama ve benzerlerinin emlak değerini hesaplarken kullandığı "değerli komşu" profili arasındaki farktan kaynaklanmaktadır. Sosyal sermaye odaklı bir yaklaşım olduğu için, sadece kapitalist bir sistem açısından "değerli" olan komşular emlak fiyatınıza değer katmaktadır.

Bu bağlamda, sadece "elit" bir muhite taşınarak sosyal sermaye arttırma gayreti yeterli değildir, uzun vadede çocuğunuzun sosyal sermayesini de biriktirmek için çaba sarf etmeniz gerekir. Bunun için de en uygun yerler sadece belli ekonomik sermayeye sahip kişilerin gidebileceği okullara çocuğunuzu göndermek olacaktır. Bu, özellikle İngiltere gibi ülkelere göç eden aileler için çok faydalı bir yöntemdir. Çünkü ne kadar paranız olsa da dil engeli ve göçmen olma durumundan dolayı sahip olunabilecek sosyal sermaye sinırlıdır. Fakat bu ailelerin çocukları için aynı durum geçerli değildir; birinci dil olarak İngilizceyi rahat konuşabileceği gibi, yetiştiğinde arkadaşlığının devam etmesi muhtemel olacak kişilerle (sosyal sermaye olarak) tanışması için üst gelir grubunun gittiği okullara çocukların gönderilmesi mümkündür. Bu da ailelerin sonraki nesilleri için önemli bir yatırımdır. 


\section{İlişkilerdeki Dönüşümün Temel Enstrümanı Olarak Okul}

Bireyin kendisiyle ve çevresiyle kurduğu ilişkinin modern kapitalist toplumda nasıl bir sosyal yapıya sahip olduğu ve İslam Ekonomisi açısından bu ilişkinin sahip olması gereken ideal doğası tanımlandıktan sonra, bu bölümde bahsi geçen ilişkilerin hem bir sebebi hem de sonucu olan "Okul"u bir kurum olarak ele alacağız.

Kurumlar, ilişkiler gibi her toplumda olan ve o toplumu oluşturan prensipler tarafından belli şekillerde inşa edilen yapılardır. Kapitalist bir toplumda ortaya çıkan eğitim kurumları ile İslam'ın ahlaki yapısının şekillendireceği eğitim kurumlarının birbirinden farklı içeriklere sahip olması ve farklı amaçlara hizmet etmesi beklenmelidir.

Eğitim kavramı bütün zaman ve coğrafyalarda var olmakla beraber kurumsal yapıları farklı şekillerde ortaya çıkmıştır. Özellikle İslam'ın ortaya çıktığı ilk dönemlerde mescitlerdeki halkalarda veya alimlerin evlerinde gerçekleșen hoca merkezli eğitim anlayışı (Siddiki, 2014: 150-153), günümüzde eğitim dendiğinde akla doğrudan okul kurumu gelecek şekilde çeşitli dönüşümlere uğramıștır. Bunun önemli sebeplerinden bir tanesi "evde eğitim" gibi farklı eğitim yöntemlerine Türkiye gibi bazı Müslüman ülkelerde hukuki olarak izin verilmemesi (Şad ve Akdağ, 2010), dolayısıyla alternatif eğitim kurumlarının hayal edilmesinin güçlüğü olabilir.

Bir kurum olarak okul, çocuklarımızın "parlak" bir geleceğe, diğer bir deyişle iyi bir maaşla işçi olma imkanına sahip olmaları için tek yol olarak gördüğümüz (Illich, 2013: 20), ulus-devlet yapısının ideolojik olarak vatandaş inşa etme (Althusser, 2014) ve kapitalist sistemin işçi üretme alanıdır (Reich, 1989). Özellikle Türkiye ve benzeri modernleşme süreçlerinden geçen ülkeler için okul ile eğitim kelimeleri özdeş hale gelmiştir.

Okuldan bir kurum olarak bahsederken sadece belli öğrencilere eğitim verilen binalardan ibaret olarak düşünmemek gerekir. Ivan Illich'in "Toplumu Okulsuzlaştırmak" (Deschooling Society) kitabında da vurguladığı gibi, "[s] adece eğitim değil, aynı zamanda, sosyal gerçekliğin bizatihi kendisi de okullaştırılmış durumdadır" (Illich, 2013: 14). Bu sebeple, toplumun bir bütün olarak okulsuzlaştırılması gerekmektedir (Illich, 2013: 15). Bunu da ancak okulsuzlaşmış bir toplumda yetișen yeni bir neslin kapitalist yapıdan bağımsız bir toplumsal yapı tahayyül edebileceğini ve ortaya koyabileceğini vurgulamaktadır (Illich, 2013: 56). Bu iddia Hz. Musa'nın kavminin çölde 40 yıl kalmak zorunda olmasını hatırlatmaktadır. Firavunun zulmünden kaçan halk, peygamberlerinden ayrı kaldıkları ilk anda tapınmak için altından buzağı yapma ihtiyacı duymuştur. Çünkü yıllarca kölelik hayatı yaşamış olan İsrailoğulları somut bir varlığa ibadet etmenin ötesine geçememişlerdir. Bu sebeple, Allah'a kul olabilecek idrak düzeyine sahip yeni bir neslin yetişmesi için çölün özgür ortamında, babalarının maruz kaldığı, zihinlerin okullaştırılma benzeri belli bir kalıba sokulması zulmünden uzakta 40 yıl geçirmeleri gerekmiștir. 
Ortaya çıkışı endüstri devrimine dayanan okul kurumunun insanlarda zihinsel bir dönüşümü gerçekleştirerek ulaşmaya çalıştığı iki temel hedef vardır. Birincisi, kapitalist üretim araçlarında bir faktör olarak yer alacak disipline edilmiş işgücünü oluşturmak (Reich, 1989), ikincisi ise ortaya çlkan ulus-devletin ihtiyaç duyduğu itaatkâr vatandaşı yaratabilmektir (Althusser, 2014). İroniktir ki, endüstriyel kapitalizmin başarılı şekilde ilerlemesinde önemli rol oynayan disipline edilmiş işgücü, şu anda ihtiyaç duyulan "kutunun dışında düşünen" ve yenilikçi/girişimci olması beklenen yeni nesil işgücü ihtiyacını karşılamadığı için Batılı entelektüel çevrelerde de eleştirilmekte ve alternatif eğitim metotları geliştirilmeye çalışılmaktadır (Robinson, 2017). Fark edileceği üzere bu eleştiriler sadece okulların yeni kapitalist düzenin "işçi" ihtiyacına cevap veremediği için getirilirken, bu çalışmada yapılmaya çalışılan çok daha ontolojik seviyede bir eleştiridir. Çünkü insanın hak ettiği, üretim sürecinin bir girdisi olarak değil, Allah'ın yarattığı en şerefli varlık olarak değerlendirilmek ve bu çerçevede eğitim görebilmektir.

Bu sebeple eğitim meselesi; (i) Eğitimin amacı, (ii) Eğitimin verilme şekli ve (iii) Eğitim müfredatının içeriği olmak üzere üç temel başlık altında ele alınacaktır.

\section{Eğitimin Amacı}

Kapitalist prensipler tarafından şekillenen okulların önemli bir amacı kapitalist üretim sisteminde bir girdi olarak kullanılacak işgücünü yetiştirmektir. Burada amaç sadece belli bir bilgi aktarımından öte, kişinin kendisini bir beşerî sermaye olarak görmesini sağlamak ve kendi kendine yatırım yapmasını sürdürmeyi sağlayacak bir bilinç aşılayabilmektir (Fischer, 2000). Yaşadığımız modern dünyada, aileler çocuklarını halihazırda beşerî sermaye olarak görmeye başladıklarından, çocuklarının iyi bir üniversiteye yerleşme ihtimallerini arttırmak için eğitim konusunda yapılan tercihlere dikkat edilmektedir (Hesapçioğlu ve Nohutçu, 2013: 193).

Ailelerin çocuklarına ait beşerî sermaye biriktirme talebi karşısında okullar, çocuklara daha ilkokuldan itibaren üniversite sınavı ve aynı formattaki önceki sınavlarda başarılı olmaları için test çözdürmekte ve mezun olduklarında iş bulmalarını kolaylaştıracak yabancı dil ve robotik kodlama gibi becerilerle onları donatmaya çalışmaktadırlar (Çakan, 2004: 109). Bu bahsedilen gayretler, daha ziyade çocuklarını özel okullara göndermeye gücü yeten ve çocuklarının kapitalist üretim sürecinde "beyaz yakalı" diye tabir edilen işçi grubuna uygun olarak yetiştirmeyi hedefleyen aileler için geçerlidir. Sosyal ve ekonomik sermaye sahibi olmayan kişiler ise daha ziyade "mavi yakalı" gruba dahil olmakta ve bunun için gerekli olan disiplini ve minimum becerileri devlet okullarında kazanmaktadırlar. Sistem içerisinde zeki olan öğrencilerin yine başarılı devlet okullarında veya özel kurumlarda burslu olarak üçüncü bir kategoriye girdikleri vaki olsa da eğitim sisteminin genelini düşününce bu durum kaideyi oluşturmaktan ziyade istisnaya tekabül etmektedir. 
Çocuğu maddi olmanın yanı sıra ebeveynin gurur duyarak sosyal çevrede prestij edinmesini sağlayacak uzun vadeli bir yatırım aracı haline getiren bu sistem, aynı zamanda özel okulların eğitimi metalaștırmasına sebep olmaktadır (Gök, 2005). Bu metalaşma neticesinde; eğitime öncelikle ticari açıdan bakan bu okullar, istihdam sağladıkları öğretmenleri fabrika işçisinden farklı görmemekte ve o şekilde maaş verip, muamele etmektedirler (Demirer, 2012: 178).

Bu amacın bir yan maddesi olarak okullar, özellikle anaokulları, halihazırda kapitalist üretim sisteminde iş bulabilmiş "şanslı" kişilerin çocuklarına bakıcılık yapmak ve çocukları aileler için çalışmaya mâni bir yük olmaktan kurtarmakla da görevlidirler (Halpern, 1999: 86). Nasıl ki huzurevleri yaşlıları çalışan kişilere yük olmaktan kurtarıyorsa, okullar da ailelerinin bakımına muhtaç olan çocuklara belli saatlerde bakıcllı yapmaktadırlar. Normal okul süresine ilave etüt saatleri ekleyerek öğrencilerin mesai saati bitimine kadar okulda kalmalarını sağlayan veya hafta sonu okulda ek derslerle eğitime devam ederek cumartesi günleri de çalışmak zorunda kalan ailelerin üzerindeki yükü alan okullar, kapitalist sistem için çocukları disipline etmenin ve iş bulmak için gerekli bilgi ve becerileri aktarmanın ötesinde "faydalarının" olduğunu göstermektedir.

İslam ekonomisi açısından bakıldığında, belli bilgi ve becerilerin edinilmesi kişinin geçimini sağlaması için önemli olsa da teknik eğitim ile hakikate ulaşmak için gereken eğitim arasında bir ayırım yapmak gereklidir. Bir zanaat veya meslek edinerek helal rızık peşinde koşmak gerekli olsa da eğitimin temelini ve amacını hakikat bilgisinin elde edilmesi oluşturmaktadır. Burada hakikat bilgisi ile kastedilen Allah'ı tanımak ve Kur'an'da belirtildiği üzere yaratılışın amacı olan O'na ibadet etmeyi öğrenmektir. Burada geçen ibadet kavramı sadece ritüelleri kapsayan dar bir anlamı değil, kişinin hayatının her anında kul olma bilinciyle hareket etmesini ifade etmektedir.

\section{Eğitimin Veriliş Şekli}

Okulda verilen eğitimi özellikle temel eğitim dönemini, "üretim yllına" göre aynı sınıfa konulan öğrencilerin tek bir müfredat doğrultusunda eğitim görmesi olarak tanımlayabiliriz (Leland ve Kasten, 2002: 8). Her ne kadar ilerleyen yıllarda seçmeli derslerle bir ölçüde çeşitlilik sunulsa da netice itibariyle aynı sınıfta olan herkesin aynı eğitime muhatap olması, bilişsel seviye, ilgi ve beceri alanları veya gelişimsel sorunlar göz ardı edilerek verilmektedir. Öğretmene karşı itaat son derece önemlidir çünkü -en azından okul sınırları içerisinde- öğrenciler için "hem bir ana hem bir baba" olan öğretmenlerin (Çelikten, 2006: 277) okul sistemi içerisindeki en önemli görevlerinden birisi öğrencinin üstlerine itaat etmeyi öğrenmesi için disipline edilmesidir (Reich, 1989).

Günümüz kapitalist üretim mantı̆̆ı açısından kıymetli olan farklı beceri ve yatkınlıkların bu tarz bir eğitim sistemiyle keşfedilemeyip aksine yitirilmesi, 
mevcut okul yapısına Batılı entelektüel kesimden de epey itiraz gelmesine ve alternatif eğitim şekilleri arayışına sebep olmaktadır (Reich, 1989; Robinson, 2017). Ancak bu bölümde mevcut eğitim sisteminin kapitalist piyasa mantığına göre şekillendirilmiş alternatiflerine odaklanmak yerine, İslam ekonomisi açısından bir değerlendirme yapılarak bu eleştirilerin ötesinde, eğitim kurumlarının merkezi kontrolü ve yetkinliğin kurumsal olarak verilmesi üzerinden bir analiz yapılacaktır.

Ivan Illich'in de değindiği gibi, merkezi bir otoriteye bağlı tüzel kişilikler tarafından yetkinlik belgelerinin (diploma veya yeterlilik sertifikalarının) veriliyor olması "okullaştırma zihniyeti içinde mantıklı gözükmektedir" (Illich, 2013: 29). Ancak, yetkinliği uzmanlar tarafından dahi kabul edilecek birçok kişinin "diploma” sahibi olmamaları sebebiyle eğitimlerinin yok hükmünde sayılması, merkezi kontrol mekanizmasının ne kadar güçlü ve okullaştırılma sürecinin ne kadar başarılı olduğunu göstermektedir. Halbuki modern öncesi Müslüman toplumların eğitim sistemine bakıldığında talebelerin yetkinlikleri bizzat kendilerine yıllarca ders vermiş olan hocalarının icazeti sayesinde olduğu ve belli bir geleneğe dayandığı görülmektedir. Burada icazeti hak eden öğrencinin modern eğitim sisteminde olduğu gibi sadece "yeterli bilgiye sahip kişi” olarak algılanmaması gerekir. Bu öğrenci, ilmî birikiminin yanında, kendisine icazet veren "hocanın talebesi" olarak anılmaya layık bir ahlaka da sahip olmuş demektir (Ertunç, 2019: 478; Schick, 2017: 241). Çünkü geleneksel eğitim anlayışımızda teorik bilgi ve onun pratik uygulaması iki ayrı alan olarak görülmemektedir. Söz konusu eğitimin, bloklar halinde sinıflarda verilen bir aktivite olmanın ötesinde topluma gömülü șekilde ve pratik ederek içselleştirilen bir eğitim olması bunun sağlanmasındaki önemli etkenlerden biridir. Teknik eğitimlerin aynı şekilde pratikten kopartılmadan, usta çırak ilişkisi içerisinde verilmesi, eğitim sürecinde sadece teknik bilginin değil, aynı zamanda İslam ahlakının da uygulamalı olarak sahada tatbik edilmesi, bu geleneksel eğitim anlayışının temellerini oluşturmaktadır (Sancakli, 2010: 4).

$\mathrm{Bu}$ anlayış, eğitime ders saatlerinin ötesinde bir anlam yüklenmesi, her anın ve hareketin eğitimin bir parçası olması gerektiği ile ilgilidir. Halbuki günümüzdeki uygulama, daha ziyade -çoğunlukla- ücreti mukabilinde dahil olunan, teknik bilginin ahlaktan ve gündelik hayattaki yansımalarından koparılmış halde kurs veya akademik programlarla öğrencilere aktarıldığı sertifika programlarından oluşmaktadır.

\section{Eğitim Müfredatının İçeriği}

Önceden ifade edildiği üzere, okullarda uygulanan eğitim müfredatları hazırlanırken, işgücü olarak kapitalist sisteme dahil olabilmek için gerekli bilgi ve becerilerin kazandırılmasına yönelik bir içerik oluşturulması amaçlanmaktadır. Mevcut ulus-devlet ve kapitalist sistemin bir aracı olan okulun, onu -daha iyi hale getirmenin ötesinde- eleştiriye tabi tutması ve yıkıcı bir etki oluşturması mümkün değildir (Hallaq, 2018). Bu sebeple okula giden ve mevcut 
müfredat üzerinden eğitim gören bir öğrencinin sisteme alternatif bir fikir üretebilmesi beklenmemelidir. Ancak eğitim sisteminin başarısızlığı veya okul harici bazı programların okula nispeten daha baskın bir yönlendirme ve şekillendirme yapması neticesinde istisnai de olsa farklı görüşler ortaya çıkmaktadır.

Bu eğitim sürecinde, içine doğduğumuz ve seçme şansımız olmadan yaşamak zorunda olduğumuz dünyayı tanımak ve anlam dünyamızı oluşturan kavramların arka planında yatan varsayımların farkına varmak genellikle mümkün olmamaktadır. Bunun başlıca sebebi bu tür bir kavramsal anlayışın kapitalist sistem içerisinde üretici bir girdi olması için eğitim alan öğrencilerin üretici kapasitesini arttıracak bir etkisinin olmamasıdır. Aksine, meydana gelen farkındalık bireylerde yabancılaşma gibi sorunlara sebep olarak üretici kapasitesine zarar verebilir. Bu farkındalık oluşamadığı için de içselleştirilmesi hedeflenen kavramlar yapısöküme uğratılarak bireyin kendi referans noktasından tekrar inşa etme veya tamamıla terk etme imkanı elde edememektedir.

Görüldüğü üzere, eğitim kavramı farklı teorik çerçeveler açısından ortak bir payda olmakla beraber, ontoloji ve epistemolojinin farklılaşması bu kavrama farklı amaç, aktarılış şekli ve içerikler yüklemektedir. İslam ekonomisi açısından değerlendirildiğinde, İllich'in (2013) vurguladığı okulsuzlaștırma kavramı ve bunu yapabilmek için gerekli olacak kavramların ve kurumların yapısökümüne uğratılması eğitim müfredatının önemli bir bölümünü oluşturmalıdır. Fakat burada kalmayıp, inşa sürecine girerek, inşa edilmesi gereken kurum ve ilişkilerin İslami kaynaklara ve tarihi tecrübeye göre nasıl yapılarda olması ve nasıl inşa edilmeleri gerektiği üzerine tartışmalar müfredata dahil edilmelidir.

\section{Sonuç ve Değerlendirme}

Bu çalışmanın temel amacı beşeri ve sosyal sermaye kavramları ve okul kurumu üzerinden eleştirel bir analiz yaparak içinde bulunduğumuz ilişki ağlarının ve kurumsal yapıların İslam ekonomisi çerçevesinden değerlendirilmesini sunmaktır. Makalenin ikinci ve üçüncü bölümlerinde sırasıyla kişinin kendisiyle ve yakın sosyal çevresiyle olan ilişkilerini kapitalist piyasa sisteminin hakim olduğu bir toplumda nasıl kurduğunu veya kurmasının teşvik edildiğini inceledik. Beşerî ve sosyal sermaye bağlamında, kendisiyle ve sosyal çevresiyle olan ilişkisinin temelini kapitalist prensiplerin mi yoksa İslam ahlak esaslarının mı belirleyeceği noktasında, kişilerin aktif olarak tercihte bulunma imkanları vardır. Bu kişisel olarak tercihte bulunma imkanı, içinde yaşanan toplulukla kurulan ilişkilerin belirlenmesi aşamasında zayıflamaktadır. Çünkü hem kişinin -çalışma faaliyetlerinin haricinde- ne kadar zamana sahip olduğu hem de bu zamanı nerelerde harcayabileceği konusunda kapitalist piyasa sisteminin etkili kısıtlamaları vardır. Çalışma saatlerinin fazla olması veya çalışma saatlerinin dışında kalan vakitlerde kişinin yeni şeyler öğrenmek gibi beșeri sermayesini arttırmaya mecbur bırakan sorumluluklar 
bu duruma örneklik teşkil etmektedir. Bu ilişkileri belirlemek için aktif bir çaba gösterilmeyerek mevcut ilişki türlerinin sürdürülmesinin arka planında yatan en önemli etken okul ve benzeri kurumların küçük yaştan itibaren insanları "işçi" olarak şekillendirmesidir.

Dördüncü bölümde okul kurumu detaylı olarak incelenerek kişilerin kendi ve çevreleriyle kurdukları ilişkileri sermaye bakış açısıyla oluşturmalarını sağlayan önemli bir kurumsal yapı ele alınmıştır. Eğitim sistemi içerisine giren öğrencilerin içinde yaşadıkları dünyanın kavramlarını sorgulamadan ve değer yüksüz şekilde algılayarak kullanmaları yerine, bu kavramları, arka planlarında yatan varsayımların ve ön kabullerin farkına vararak kullanmaları çok önemlidir. İslam ekonomisine uygun bir eğitim sisteminin, İslam'ın varlık ve bilgi anlayışları temelinde kavramlar üreterek okul kurumunun şekillendirmesinin ötesine giderek bir inşa çabasına girmesi de bu eğitimi önemli bir parçasıdır.

\section{Kaynakça}

Al-Bouti, R. (2005). Dawabit al-Maslaha fi al-Shari'ah al-Islamiyya. Resalah Publishers.

Al-Sadr, M. B. (1981). Our Economy. Dar Al-Ta’aruf Press, Beirut.

Althusser, L. (2014). On the reproduction of capitalism: Ideology and ideological state apparatuses. Verso.

Asutay, M. (2007). A Political Economy Approach to Islamic economics: Systemic Understanding for an Alternative Economic System. Kyoto Bulletin of Islamic Area Studies, 1(2), 3-18.

Atçl, A. (2018). Scholars and sultans in the early modern Ottoman Empire. New York : Cambridge University Press.

Auda, J. (2010). Maqasid al-shariah as philosophy of Islamic law: A systems approach. Islamic Book Trust.

Bourdieu, P. (1986). The Forms of Capital. İçinde J. G. Richardson (Ed.), Handbook of Theory and Research for the Sociology of Education (ss. 241-258). Greenwood.

Boyles, D. (2000). American Education and Corporations: The Free Market Goes to School. Taylor \& Francis.

Choudhury, M. A. (2018). Tawhidi Islamic economics in reference to the methodology arising from the Qur'ān and the Sunnah. ISRA International Journal of Islamic Finance, 10(2), 263-276.

Çakan, M. (2004). Öğretmenlerin ölçme-değerlendirme uygulamaları ve yeterlik düzeyleri: İlk ve ortaöğretim. Ankara Üniversitesi Eğitim Bilimleri Fakültesi Dergisi, 37(2), 99-114.

Çelikten, M. (2006). Kültür ve Öğretmen Metaforları. Erciyes Üniversitesi Sosyal Bilimler Enstitüsü Dergisi, 1(21), 269-283. 
Demirer, D. K. (2012). Eğitimde piyasalaşma ve öğretmen emeğinde dönüşüm. Çalışma ve Toplum, 1(32), 167-186.

Ducatel, K. (1998). Learning and skills in the knowledge economy. DRUID.

Ertunç, Ç. Ö. (2019). Geleneksel Sanatlarda Eğitim Modeli ve İcazet Geleneği. ÍSTEM, $34,477-487$.

Fischer, G. (2000). Lifelong Learning-More Than Training. Journal of Interactive Learning Research, 11(3), 265-294.

Floress, K., Prokopy, L. S., ve Allred: B. (2011). It's Who You Know: Social Capital, Social Networks, and Watershed Groups. Society \& Natural Resources, 24(9), 871-886.

Gök, F. (2005). Üniversiteye giriște umut pazarı: Özel dershaneler. Eğitim Bilim Toplum, 3(11), 102-109.

Güngör, M. (1993). Cessâs. İçinde TDV İslam Ansiklopedisi (C. 7: 427-428). TDV İslâm Araştırmaları Merkezi. /zeyd-b-sabit

Hallaq, W. B. (2018). Restating Orientalism: A critique of modern knowledge.

Halpern, R. (1999). After-school programs for low-income children: Promise and challenges. The future of children, 81-95.

Hesapçioğlu, M., ve Nohutçu, A. (2013). VELÎLERIN ÖZEL OKUL TERCIHLERINII ETKİLEYEN FAKTÖRLER VE ÖZEL OKULLARIN REKLAM STRATEJILLERI. Marmara Üniversitesi Atatürk Eğitim Fakültesi Eğitim Bilimleri Dergisi, 11(11), 183-202.

Ignatowski, G., Stopczynski, B., ve Trebska, J. (2019). Paradox of Nepotism in Enterprises in Poland and Ukraine: Social Capital Perspective. Marketing and Management of Innovations, 2, 295-313.

Ihlen, Ø. (2005). The power of social capital: Adapting Bourdieu to the study of public relations. Public Relations Review, 31(4), 492-496.

Illich, I. (2013). Okulsuz toplum (M. Özay, Çev.; 8. bs). Şule Yayınları.

Jorgenson, D. W., ve Siebert, C. D. (1968). Optimal Capital Accumulation and Corporate Investment Behavior. Journal of Political Economy, 76(6), 1123-1151.

Khasawneh: (2010). Factors Influencing the Career Planning and Development of University Students in Jordan. Australian Journal of Career Development, 19(2), 41-48.

Knapper, C., ve Cropley, A. J. (2000). Lifelong Learning in Higher Education. Psychology Press.

Laroche, M., Mérette, M., ve Ruggeri, G. C. (1999). On the Concept and Dimensions of Human Capital in a Knowledge-Based Economy Context. Canadian Public Policy / Analyse de Politiques, 25(1), 87-100.

Leland, C. H., ve Kasten, W. C. (2002). Literacy Education for the 21st Century: It's Time to Close the Factory. Reading \& Writing Quarterly, 18(1), 5-15. 
Macdonald, M. (1991). Post-Fordism and the Flexibility Debate. Studies in Political Economy, 36(1), 177-201.

Magnuson, C. S., ve Starr, M. F. (2000). How Early Is Too Early to Begin Life Career Planning? The Importance of the Elementary School Years. Journal of Career Development, 27(2), 89-101.

Murphey, R., ve Stapleton, K. (2019). A history of Asia. New York: Routledge.

Orman: (2015). İslam Entelektüel Geleneğinde İktisadi Boyutun Teșekkülü: Şeybânî, Serahsî ve Kitâbu'l-Kesb (II). İslam Ekonomisi ve Finansı Dergisi, 1(2), 23-67.

Pillai, K. G., Hodgkinson, G. P., Kalyanaram, G., ve Nair: R. (2017). The Negative Effects of Social Capital in Organizations: A Review and Extension. International Journal of Management Reviews, 19(1), 97-124.

Polanyi, K. (2001). The Great Transformation: The Political and Economic Origins of Our Time (2nd bs). Beacon Press.

Powell, W. W., ve Snellman, K. (2004). The Knowledge Economy. Annual Review of Sociology, 30(1), 199-220.

Rawlinson, H. G. (2001). Ancient and medieval history of India. Bharatiya Kala Prakashan.

Reich, R. B. (1989). The resurgent liberal: (And other unfashionable prophecies). Random House.

Robinson, K. (2017). Out of our minds: Learning to be creative.

Rosen: (1983). Specialization and Human Capital. Journal of Labor Economics, 1(1), 43-49.

Rotimi, A. (2005). Paradox of "Progress": The Role of Western Education in the Transformation of the Family in Nigeria. The Anthropologist, 7(2), 137-147.

Sancakli: (2010). Ahilik Ahlâkının Oluşumunda Hadislerin Etkisi. İnönü Üniversitesi İlahiyat Fakültesi Dergisi, 1(1), 1-28.

Schick, İ. C. (2017). İslâmî Kitap San'atlarında Standartlaşma: Usta-Çırak İlişskisi ve İcazet Geleneği. Osmanlı Araştırmaları, 49(49), 231-266.

Schultz, T. W. (1961). Investment in Human Capital. The American Economic Review, 51(1), 1-17.

Seth: (2007). Subject Lessons: The Western Education of Colonial India. Duke University Press.

Shāțibī, I. ibn M. (1999). El-Muvâfakât: İslâmi İlimler Metodolojisi. İz.

Siddiki, C. (2014). Mescitten Medreseye Dönüşümün Kurumsal ve Düşünsel Açıdan İncelenmesi. Karadeniz Teknik Üniversitesi İlahiyat Fakültesi Dergisi (KTUIFD), 1(2), 147-163. 
Slomczynski, K., ve Tomescu-Dubrow, I. (2005). Friendship patterns and upward mobility: A test of social capital hypothesis. Polish Sociological Review, 151(3), 221235.

Şad: N., ve Akdă̆, M. (2010). EVDE EĞİTìM. Milli Eğitim Dergisi, 40(188), 19-31.

Villalonga-Olives, E., ve Kawachi, I. (2017). The dark side of social capital: A systematic review of the negative health effects of social capital. Social Science \& Medicine, 194, 105-127.

Vivarelli, M. (2014). Innovation, Employment and Skills in Advanced and Developing Countries: A Survey of Economic Literature. Journal of Economic Issues, 48(1), 123154.

Wolf, B. M., ve Wright, L. (2014). Designing Curriculum for Real-World International Business Needs. Journal of Teaching in International Business, 25(3), 165-184.

Yilmaz, Y. (2012). Hz. Peygamber Dönemi Eğitimine Genel Bir Bakış. Dini Araştırmalar, 15(40).

Zingat. (2017). Bir Kitabı Kaç Günde Bitiriyorsun Çankaya? https://www.youtube. com/watch?v=LKPFwvAyK2U

Araştırma Makalesi/Research Article ADAM AKADEMİ Sosyal Bilimler Dergisi, 11(1)

Başvuru/Submission: 16. 03.2021 DOI: 10.31679/adamakademi.898087

Kabul/Acceptance: 12. 06.2021 
